\title{
Dynamic modelling of the potential habitat loss of endangered species: the case of the Canarian houbara bustard (Chlamydotis undulata fuerteventurae)
}

\author{
Isabel Banos-González ${ }^{1,2}$ - C. Terrer ${ }^{3}$ - J. Martínez-Fernández ${ }^{4}$. \\ M. A. Esteve-Selma ${ }^{1}$ L. M. Carrascal ${ }^{5}$
}

\begin{abstract}
In this work, we apply a dynamic modelling approach to analyse the habitat loss of the Canarian houbara bustard (Chlamydotis undulata fuerteventurae). This tool allows us to assess the effects of the socio-economic and environmental interactions on the factors threatening the habitat and to carry out a prospective analysis. The results show a potential habitat loss of around $13 \%$ during the period 1996-2011, the land uptake and increase in new roads and tracks being the factors contributing most. After model testing, a set of scenarios was explored. Under the business as usual (BAU) scenario, around $20 \%$ of the habitat would be lost by the end of the period considered (2012-2025). The impact of the economic growth scenario on the habitat would mean an additional loss of around $21 \%$ with respect to BAU, whereas under the recession scenario, the loss might be around $6.5 \%$ lower than BAU. The policy of restoration of
\end{abstract}

Electronic supplementary material The online version of this article contains supplementary material

Isabel Banos-González

ibbg1@um.es

1 Department of Ecology and Hydrology, University of Murcia, Campus de Espinardo, 30100 Murcia, Spain

2 Department of Geoscience, University of Fribourg, 4, Chemin du Musée, 1700 Fribourg, Switzerland

3 Department of Life Sciences, Imperial College London Silwood Park, Ascot SL5 7PY, UK

4 New Water Culture Foundation, C/ Pedro Cerbuna, $12,4^{\circ} \mathrm{D}$, 50009 Zaragoza, Spain

Department of Biogeography and Global Change, Museo Nacional de Ciencias Naturales, CSIC, C/José Gutiérrez Abascal 2, 28006 Madrid, Spain gavias - traditional farming systems - would suppose an additional loss of almost $6 \%$, relative to BAU. If this policy took place under economic growth conditions, it might mean an additional loss of almost $28 \%$ relative to BAU. These results point to the existence of a potential trade-off between the recuperation of ecosystem services offered by restored gavias and the conservation of the houbara habitat, which must be addressed within the management processes, as well as to the need for compensatory measures to guarantee the conservation goals.

Keywords Chlamydotis undulata fuerteventurae $\cdot$ Habitat loss · Threatening factors · Dynamic model · Arid island . Scenarios

\section{Introduction}

Conservation of endangered species in populated or managed areas requires interdisciplinary approaches, which facilitate an integral knowledge of habitat use and population size, as well as the dynamic of their threatening factors and their interactions. The systemic perspective of the dynamic modelling approach provides a framework for managing change and complexity by understanding the dynamic interactions, delays and feedbacks embedded in complex systems (Rasmussen et al. 2012; Zhao and Zhong 2015). Furthermore, system dynamic models (SDMs) allow the identification of plausible future scenarios and the major drivers of change and, thus, enable decision makers to anticipate the long-term consequences of their decisions and actions, as well as the unintended consequences of policies and strategies (Jørgensen and Bendoricchio 2001; Martínez-Fernández et al. 2013). The application of the system dynamics approach has numerous advantages, due to its capacity to conceptualise the complex interrelations and to facilitate their comprehension and 
monitoring (Martínez-Moyano and Richardson 2013; Kelly et al. 2013), thus generating useful information for decisionmaking (Voinov and Shugart 2013).

This dynamic approach has proven very useful to facilitate the implementation of integrated management in insular systems (González et al. 2008; Jørgensen and Nielsen 2015), as well as to assess the effects of the interactions between socioeconomic and environmental aspects on biodiversity, including the case of flagship species in arid environments (Silva et al. 2010; Pérez et al. 2012).

In this paper, we focus on the dynamics of the arid island of Fuerteventura (The Canary Islands, Spain) and one of its flagship species, the Canarian houbara bustard (Chlamydotis undulata fuerteventurae), to show how the model of the sustainability of Fuerteventura (FSM), built following the system dynamics methodology (Forrester 1961), could represent a helpful tool for the management of populated areas and the conservation of their threatened species.

The houbara bustard, houbara hereinafter, is a mediumsized bird inhabiting arid plains and stony hills of low grade, coastal plains and consolidated sandy areas. Classified as "vulnerable" (IUCN 2009), it is divided into two subspecies, C. u. undulata and C. u. fuerteventurae. Whereas the former is distributed from northern Mauritania to Egypt (Bourass and Hingrat 2015), the latter is a Canarian endemic subspecies designated as "in danger" on the Spanish Red List (Lorenzo 2004). It is one of the Canarian terrestrial birds with the smallest distribution area, with almost all the population living exclusively in Lanzarote and Fuerteventura (Martín and Lorenzo 2001; Carrascal et al. 2008; Schuster et al. 2012).

The available censuses reviewed herein for 1994 (Martín et al. 1997), 2004/2006 (Carrascal et al. 2006; Lorenzo 2005; Lorenzo et al. 2007; Carrascal et al. 2008) and 2011 (Schuster et al. 2012) show a $29 \%$ decrease over the period 2004/2006 to 2011 (Schuster et al. 2012). The loss of habitat seems to be the main factor threatening the houbara population (Lorenzo 2004; Carrascal et al. 2008). The houbara habitat in Fuerteventura has suffered a series of negative effects throughout recent decades as a consequence of uncontrolled urbanisation, leisure and backcountry motor sport activities (e.g., quads, motocross), which have expanded within the houbara habitat (Martín and Fernández-Palacios 2001; Palacios and Tella 2003). In addition, new roads and unpaved tracks have spread all over the island, fragmenting the houbara habitat and causing disturbances to the populations of houbara (Palacios and Tella 2003; Carrascal et al. 2008), mainly during the reproductive season. These factors have been previously found to be negative in Fuerteventura, as well as in other places sheltering populations of other houbara subspecies, like North Africa (Hingrat et al. 2007).

Despite the expansion of tourism and urbanisation in Fuerteventura over the last few decades, the changes in the amount of habitat available for the houbara have not been deeply studied. A better understanding of the recent dynamics of the factors threatening the potential habitat of houbara is essential to advance specific protection mechanisms (Lorenzo 2004) and to implement comprehensive policies regarding sustainable development and conservation of the biodiversity (Otto et al. 2007).

Moreover, prospective analyses are also necessary to explore the potential risks in the medium and long term. Considering this aim, in this work, we address the following objectives:

1. To develop a dynamic model of the houbara potential habitat, linking the main factors threatening the habitat to the general dynamics of Fuerteventura.

2. To determine which of the identified threatening factors have contributed most to the total loss of potential habitat in the recent period (1996-2011).

3. To use the model to assess the expected effects of different future scenarios and policy options on the houbara potential habitat.

\section{Material and methods}

\section{Study area}

Fuerteventura island is located $84 \mathrm{~km}$ from the north-west coast of Africa (N $\left.28^{\circ} 27^{\prime}, \mathrm{W} 14^{\circ} 00^{\prime}\right)$. It has an arid climate with an average annual rainfall below $150 \mathrm{~mm}$. The biodiversity in Fuerteventura is moderate, but the degree of endemism is very high: 139 endemic species and subspecies, representing $4.7 \%$ of the total surveyed species (Arechavaleta et al. 2010). The vegetation is characterised by xerophytic shrubs, therophytes and perennial grass species (Carrascal et al. 2012), which in many areas show evidence of degradation due to overgrazing by goats (RodríguezRodríguez et al. 2005; Gangoso et al. 2006). There are also extensive areas with rocky outcrops, bare soils, dunes and cultural landscapes with "gavias." Gavias represent a traditional farming system which allows a diverse and productive form of agriculture based on water harvesting techniques, with no use of conventional irrigation or chemical or organic fertilisers (Díaz et al. 2011). In the last few decades, the traditional productive activities (ranching, artisanal fishing and farming in gavias) have been mainly substituted by tourism and related activities. Tourism has represented the main driving force of the socio-economic and environmental changes on the island, concentrated mostly along the coast (FernándezPalacios and Whittaker 2008; Santana-Jiménez and Hernández 2011), which may be considered as threats to the houbara population, due to the loss of habitat (Lorenzo 2004; Carrascal et al. 2008). 


\section{Contribution ratio of factors determining the houbara potential habitat}

We generated the houbara potential habitat map based on the environmental characteristics that determine the presence of the houbara in Fuerteventura, considering the quantitative information provided by Carrascal et al. (2008) and other studies dealing with the habitat preferences of the species (mainly other qualitative factors; Martín et al. 1996, 1997; Lorenzo 2004; Carrascal et al. 2006; Lorenzo et al. 2007). Information on the steppe bird community on the island (population densities in different habitats) can be found in Seoane et al. (2011) and Carrascal et al. (2012).

The significant predictors of the presence of the houbara were (i) slope, (ii) density of unpaved tracks, (iii) density of paved roads, (iv) density of urban areas, (v) soil grain size and (vi) agricultural use cover (Table 1). The slope and the density of urban areas, roads and tracks were implemented quantitatively by selecting as potential habitat all those areas with values for these factors falling within the ranges in Table 1 (data obtained from Carrascal et al. 2008). Slopes were determined using the slopes map (GRAFCAN). Roads, tracks and cities negatively impact the habitat, and their impact on the total habitat was estimated on a density basis, for example, houbaras were usually present only in areas with less than $103.5 \mathrm{~m}$ of roads per 20 ha of habitat (Carrascal et al. 2008). The effect of urban areas was determined through the density of urban roads, extracted from the street map (GRAFCAN), and using the same range as paved roads (Table 1). The rest of the roads connecting cities, as well as unpaved tracks, were digitised from orthophotos taken in 2002. For the soil grain criterion, only soils that ranged from compact sandy soils to loose dunes were selected (Carrascal et al. 2008) using the lithology map (GRAFCAN). Regarding agricultural uses, while a sporadic source of food resources, active gavias are also a source of human interference (Lavee 1985; Hingrat et al. 2007) and do not constitute potential habitat of the houbara. However, abandoned gavias may shelter low densities of houbaras, also referred to as secondary habitat (Martín et al. 1996; Seddon and van Heezik 1996), and were selected as potential habitat of the houbara, whereas the other, more intensive agricultural uses were excluded, using the land use map of 2002 (GRAFCAN).

Urban settlements were eliminated based on the density of paved roads (Carrascal et al. 2008). Areas of human disturbance that clearly limit the presence of the houbara were also removed, such as airports and industrial parks.

By GIS procedures, the aforementioned maps were treated and reclassified individually with $30-\mathrm{m}$ grid size resolution and overlapped to estimate the potential houbara habitat in 2002 (Fig. 1), the year of reference, since all the required information were available. Then, each factor-specific contribution ratio to the habitat loss was obtained. To calculate the ratio of habitat loss due to roads, for example, the potential habitat when all factors are considered and the habitat when the negative effect of roads is not accounted for were calculated, with the difference between them being the habitat loss driven by roads. The relationship between the habitat loss and the number of kilometres of roads on the island was used to obtain the number of hectares lost per kilometre of road. These ratios were later used to parameterise the houbara sector in the general dynamic model of the sustainability of Fuerteventura (Table 2).

\section{Dynamic modelling of the houbara potential habitat}

The model of the houbara potential habitat is included in a more general dynamic system model of the sustainability of Fuerteventura (FSM), developed as a tool to improve the understanding of the key processes of this socio-ecological system (Jørgensen and Bendoricchio 2001).
Table 1 Factors and ranges falling within the houbara preferences

\begin{tabular}{|c|c|c|}
\hline Factor & $\begin{array}{l}\text { Ranges or categories falling within the } \\
\text { houbara preferences }\end{array}$ & Data source \\
\hline Slope & Up to $8.4 \%$ (Carrascal et al. 2008) & Slope map (GRAFCAN) \\
\hline Soil grain size & $\begin{array}{l}\text { Sandy soils or small rocks, never over the } \\
\text { bedrock. Qualitative (Lorenzo et al. 2007). }\end{array}$ & Lithology map (GRAFCAN) \\
\hline Vegetation & $\begin{array}{l}\text { All but tall vegetation plus bare ground. } \\
\text { Qualitative (Carrascal et al. 2008) }\end{array}$ & Vegetation map 2002 (GRAFCAN) \\
\hline Land use & $\begin{array}{l}\text { Abandoned gavias. Qualitative } \\
\quad \text { (Carrascal et al. 2008) }\end{array}$ & Based on land use map 2002 (GRAFCAN) \\
\hline $\begin{array}{l}\text { Urban } \\
\text { settlements }\end{array}$ & $\begin{array}{l}\text { Up to } 103.5-\mathrm{m} \text { street density/20 ha } \\
\text { (Carrascal et al. 2008) }\end{array}$ & $\begin{array}{l}\text { Generated in this work based on the } \\
2002 \text { street maps (GRAFCAN) }\end{array}$ \\
\hline Density of tracks & Up to $421.5 \mathrm{~m} / 20$ ha (Carrascal et al. 2008) & $\begin{array}{l}\text { Generated in this work } \\
\text { (digitised from ortophoto 2002) }\end{array}$ \\
\hline $\begin{array}{l}\text { Density of paved } \\
\quad \text { roads }\end{array}$ & Up to $103.5 \mathrm{~m} / 20$ ha (Carrascal et al. 2008) & $\begin{array}{l}\text { Generated in this work } \\
\text { (digitised from ortophoto 2002) }\end{array}$ \\
\hline
\end{tabular}


Fig. 1 Location of the potential habitat of the houbara in Fuerteventura (The Canary Islands), urban areas (residential and tourist facilities) and infrastructures (road and tracks). Source: GRAFCAN and digitised orthophotos from 2002
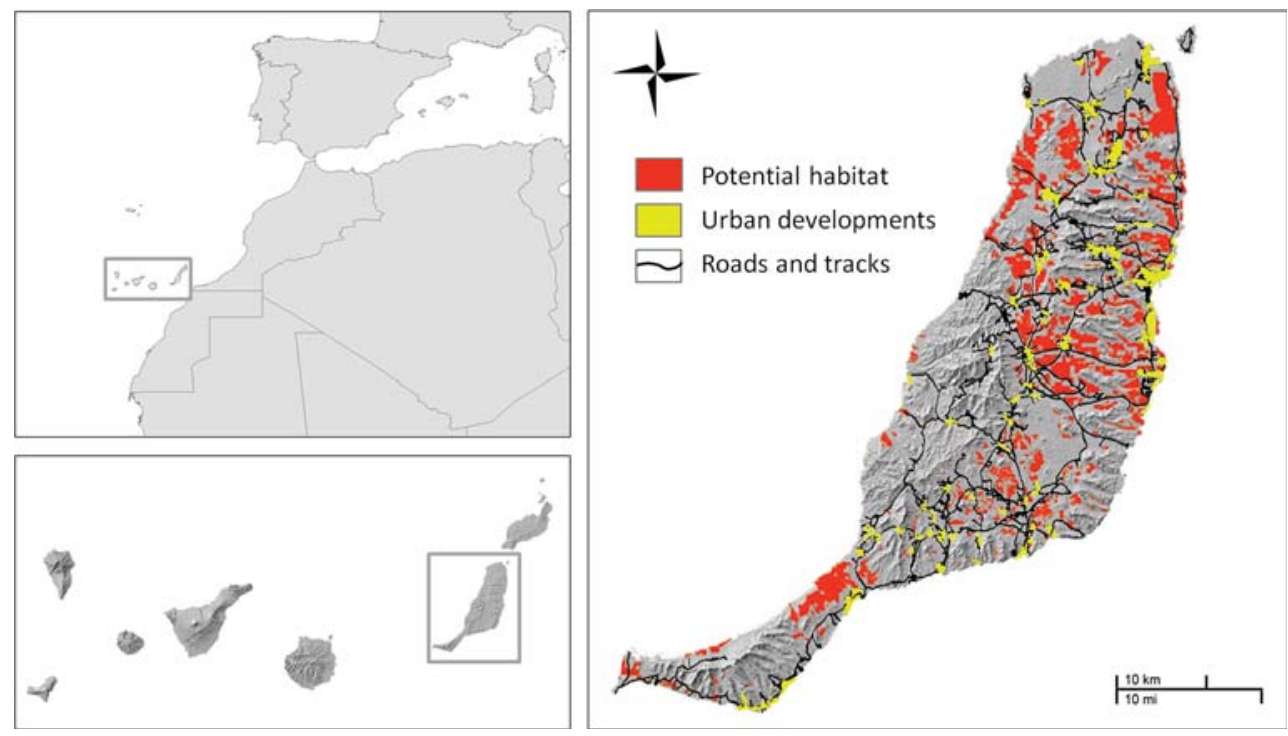

The FSM includes 520 variables (see Supplementary material) and has five model sectors: flagship species, sociotouristic, land use, water use and environmental quality (Fig. 2). All the model variables and parameters were defined and formulated starting from scientific literature and the available information. For parameters with no available data, an automatic calibration process was carried out (Oliva 2003).

The flagship species sector considers two key species in Fuerteventura, the Egyptian vulture (Neophron percnopterus majorensis) and the Canarian houbara bustard, together with the factors driving their changes with time, which depend on the processes taking place in the socio-touristic and land use sectors. The socio-touristic sector takes into account tourist and resident population dynamics. The land use sector keeps track of the changes among different types of land use: natural vegetation, where high-quality and low-quality vegetation areas are considered, in terms of the potential - unalteredand actual vegetation according to the Canary Islands vegetation map (del Arco Aguilar et al. 2010); agricultural areas (active gavias, abandoned gavias and irrigated crops) and urban uses and infrastructures (residential, hotel and non-hotel tourist accommodation, golf courses, roads and tracks). The water use sector includes the main water sources and demands, whereas the environmental quality sector takes into account the energy production and demands of different sectors, $\mathrm{CO}_{2}$ emissions and waste generation.

Table 2 Factor-specific contribution ratios to the habitat loss

\begin{tabular}{lll}
\hline Factor & Contribution ratio to habitat loss & Units \\
\hline Paved roads & 15.509 & ha $/ \mathrm{km}$ \\
Unpaved roads & 8.42 & ha $/ \mathrm{km}$ \\
Urban areas & 0.119 & Dimensionless \\
Active crops & 0.117 & Dimensionless \\
\hline
\end{tabular}

The model allows the understanding of the main components of the island and their changes over time, as well as the synergies and interactions between them, such as interactions between the demographic and socio-economic processes, the main land use changes, the binomial water energy and the effects of grazing on the natural vegetation and on the carrying capacity of the island for the Egyptian vulture.

The model was calibrated for the 1996-2011 period. Model testing procedures (including dimensional consistency tests, sensitivity analysis and extreme condition tests) and the comparison of observed data with model simulations were successfully performed, suggesting that the model may be used to explore the potential response under a set of scenarios (Barlas 1996). A fuller description of the model testing results is provided in Appendix 1. A general model overview can be found in Banos-González et al. (2013, 2015). In this paper, we focus on the houbara potential habitat model sector (Fig. 2).

We have considered two state variables for the houbara potential habitat: the primary and secondary habitats, differing in houbara density (Lorenzo et al. 2007; Martín et al. 1997). The houbara model sector takes into account the effects of other model variables representing the main factors governing the habitat loss, basically land use changes. The primary and secondary potential habitats are affected by land use changes, particularly the increase in urban areas (residential and tourist facilities) and infrastructures (road and tracks), which remove both types of habitat, and by the increase in active crops (gavias and irrigated crops), which reduce the area of abandoned gavias, part of the secondary habitat (Eq. 1 and Eq. 2). The urban sprawl is promoted by the tourist and resident population demands. The demand for new roads depends on the total population (both the resident and tourist populations), whereas the demand for new tracks is based on the resident population, since tracks are mainly used by the rural communities. Finally, the area of active crops changes according to 
Fig. 2 Sector of the houbara potential habitat

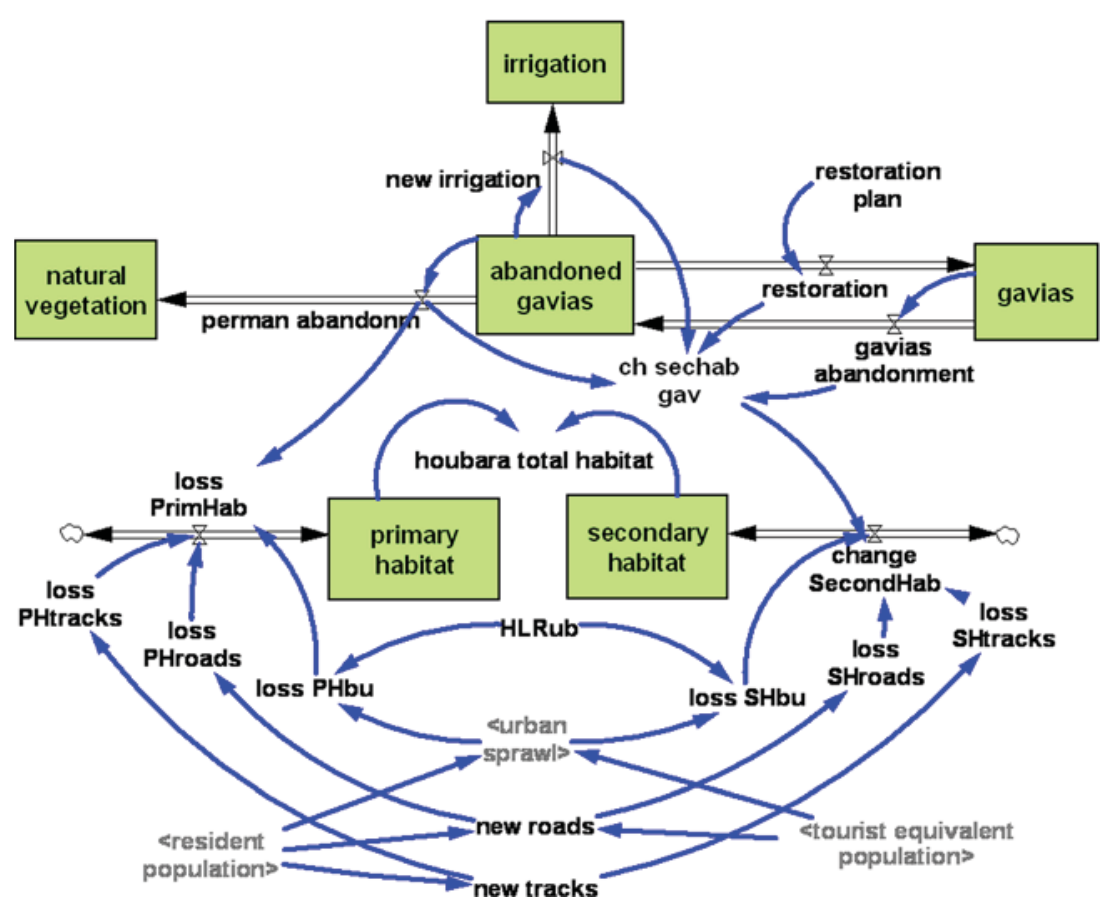

irrigation and gavias restoration measures. The main parameters of the houbara model sector correspond to the previously established contribution ratio of each threatening factor (urban areas, roads, tracks and active crops) to the habitat loss (Table 2). The rate of change in primary potential habitat for the houbara $\left(c h_{P H}\right)$ was calculated as

$$
c h_{P H}=\left(\text { par }^{*} P H P_{p a}\right)-\left(b u^{*} P H P_{b u}\right)-\left(n r^{*} P H P_{n r}\right)-\left(n t^{*} P H P_{n t}\right)
$$

where par is the abandoned gavias to natural vegetation succession ratio; $P H P_{p a}$ is the proportion of natural vegetation which is part of the primary habitat; $b u$ refers to the annual change of urban areas; $P H P_{b u}$ is the proportion of these urban areas which negatively affect the primary habitat; $n r$ and $n t$ denote the new paved roads and unpaved tracks which appear annually on the island, respectively; $P H P_{n r}$ and $P H P_{n t}$ are the proportion of the new roads and tracks which negatively affect the primary habitat, respectively.

The rate of change in secondary potential habitat for the houbara $\left(c h_{S H}\right)$ was calculated as

$$
\begin{aligned}
c h_{S H}= & \left(c h_{a g} * S H P_{a g}\right)+\left(\operatorname{par}^{*} S H P_{p a}\right)-\left(b u^{*} S H P_{b u}\right) \\
& -\left(n r^{*} S H P_{n r}\right)-\left(n t^{*} S H P_{n t}\right)
\end{aligned}
$$

where $c h_{a g}$ refers to the annual changes in abandoned gavias area (from and to active gavias); $S H P_{a g}$ is the proportion of abandoned gavias which form part of the secondary habitat; par is the abandoned gavias to natural vegetation succession ratio; $S H P_{p a}$ is the proportion of natural vegetation which is part of the secondary habitat; $b u$ refers to the annual change of urban areas; $S H P_{b u}$ is the proportion of these urban areas which negatively affect the secondary habitat; $n r$ and $n t$ denote the new paved roads and unpaved tracks which appear annually on the island, respectively; $S H P_{n r}$ and $S H P_{n t}$ are the proportion of the new roads and tracks which negatively affect the secondary habitat, respectively.

\section{Scenario analysis}

The FSM has been applied to assess the impact of several scenarios and management measures on the houbara potential habitat in the long term (2012-2025). These are relatively probable scenarios. The selection of these scenarios was based on the results of the sensitivity analysis (Results of a detailed sensitivity analysis of the houbara potential habitat model sector and Appendix 1), since the most sensitive parameters are related to the socio-touristic dynamics and the change in abandoned gavias. In this paper, we focus on the following scenarios:

s.0) Business as usual (BAU) scenario. Observed trends are maintained - no change in model parameters. The macroeconomic variables (the Canarian GDP, the GDP of the most important markets for outbound tourism and the tourist prices index) were calculated on the basis of the 1996-2011 average behaviour.

s.1) Scenario of economic growth. This is defined by the macroeconomic variables showing an average behaviour similar to the 1996-2007 trend, which means around 1.35 times greater than under BAU. 
s.2) Scenario of economic recession. This is defined by the macroeconomic variables showing an average behaviour similar to the 2008-2011 period, when they had negative values.

s.3) Gavias restoration. Under this management option, promoted by the Island Council, the abandoned gavias are restored using the recycled wastewater generated on the island, to contribute to an increase in the crop production and a decrease in the grazing pressure on highquality natural vegetation, among other reasons. This scenario maintains the macroeconomic variables used in the BAU scenario.

s.4) Gavias restoration under economic growth scenario.

s.5) Gavias restoration under economic recession scenario.

\section{Results}

\section{Contribution ratios to habitat loss}

For year 2002, a total of 29,633 ha of potential habitat (17.86\% of the island) was estimated, including 1920 ha of abandoned gavias as part of the secondary habitat. Table 2 presents the factor-specific contribution ratios to the habitat loss.

\section{6-2011 simulation period}

Within the simulation period, there are only estimations of the potential habitat for years 1996, 2002 and 2011, for which the cartographical information required to obtain the maps was available. The model results for these years are consistent with such estimations (Fig. 3a), despite the scarce number of observed data (Appendix 1).

The combined effect of the factors threatening the houbara habitat led to a decrease from around 30,000 ha in 1996 to around 26,000 in 2011 (Fig. 3a). The primary habitat decreased by around $11 \%$ with respect to the area of around 11,000 ha in 1996, whereas the secondary habitat decreased by nearly $15 \%$ with respect to the area of around 19,000 ha in 1996 (Fig. 3b). The $13.3 \%$ loss of total potential habitat is mainly explained by the increase in urban areas (Fig. 4a), roads (Fig. 4b) and tracks (Fig. 4c). Land uptake is caused by the rise in the socio-touristic activity and in the total population, which also leads to new roads. The increase in tracks is explained by the growth of the resident population. Roads had a higher unitary impact on the houbara habitat than tracks, although, given the high track density, the aggregated effect of the latter was bigger. The rise in active crops, due to irrigation and - particularly - to a local policy of gavias restoration (Fig. 4d), reduced the area of abandoned gavias and therefore negatively affected the houbara secondary habitat, which decreased at a slightly higher rate than the primary habitat (Fig. 3b).

Between 1996 and 2011, there was, on average, an annual habitat loss of 268 ha, a $0.89 \%$ annual loss ratio of the total habitat. Over this period, the loss ratio showed a clear tendency to increase, despite a high interannual variability. The factor which contributed most to this loss was land uptake due to urban expansion (137 ha per year, on average), although the impact of the disturbances caused by roads and tracks (86 ha per year, on average) was not far from the loss caused by direct habitat transformation (Fig. 5).

\section{Scenario analysis (2012-2025) results}

Under the BAU scenario, the houbara potential habitat would decrease to around 20,700 ha (Fig. 6a) at an average loss ratio of 394 ha/year. This means around $19.7 \%$ less in 2025 , due to urban sprawl and the increasing demand for paved roads and tracks (Fig. 6b).

Under an economic growth scenario, around 6100 ha of potential habitat, almost $24 \%$, would be lost over the $2012-$ 2025 period. This represents an additional loss of around $21 \%$ with respect to the BAU scenario, at the end of this period.

The habitat loss under an economic recession scenario would be around $18.4 \%$ throughout the 2012-2025 period, with an average loss ratio of around 369 ha/year (Fig. 6b). It
Fig. 3 a Model results (19962011) and observed data (1996, 2002 and 2011) for the total houbara potential habitat in Fuerteventura. b Model results for the primary and secondary houbara habitats
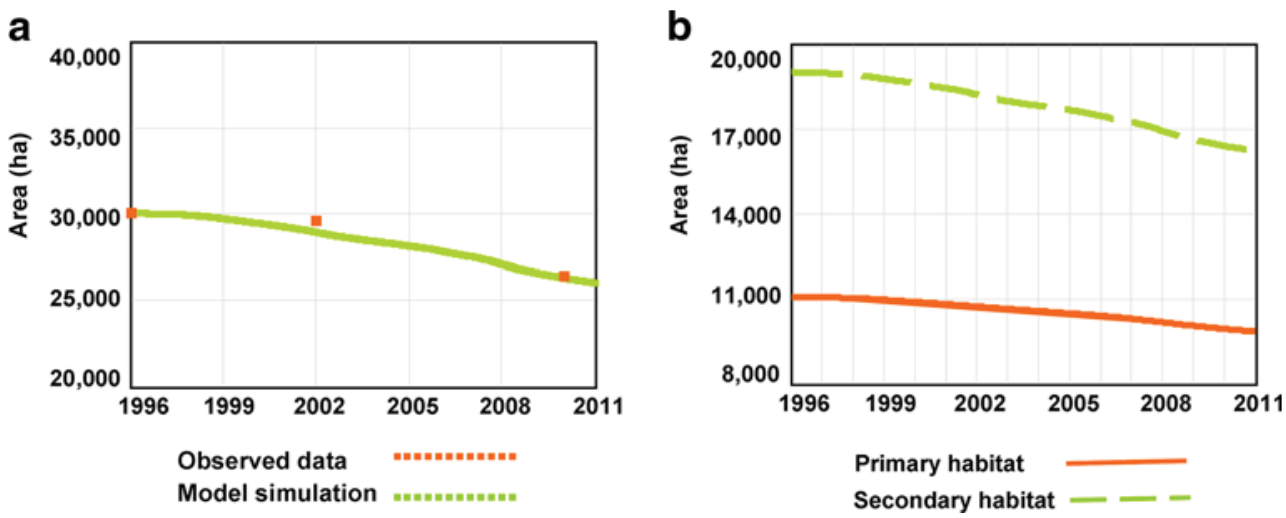
Fig. 4 Observed data and simulation results in the period 1996-2010 for the factors affecting the houbara potential habitat. a Urban area, b length of roads, $\mathbf{c}$ length of tracks, and $\mathbf{d}$ area of active gavias a

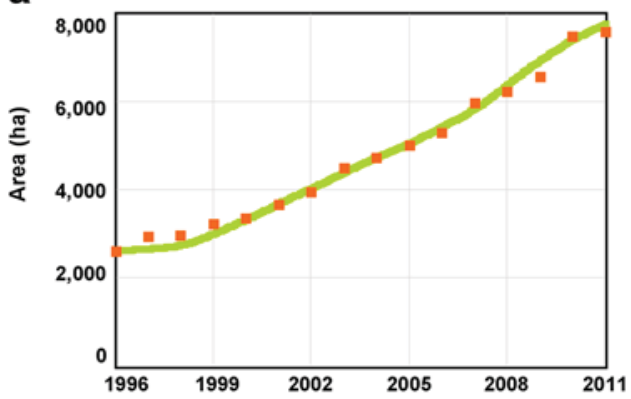

a

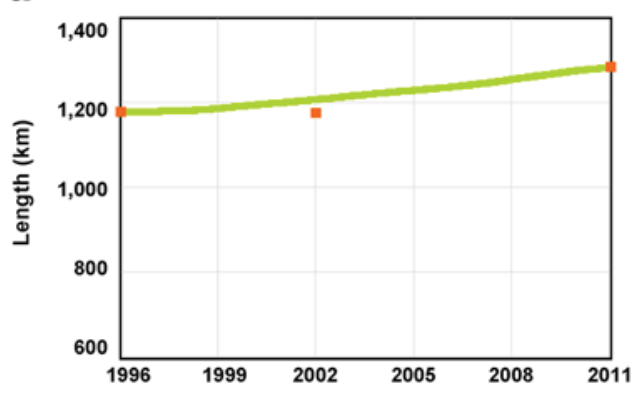

b

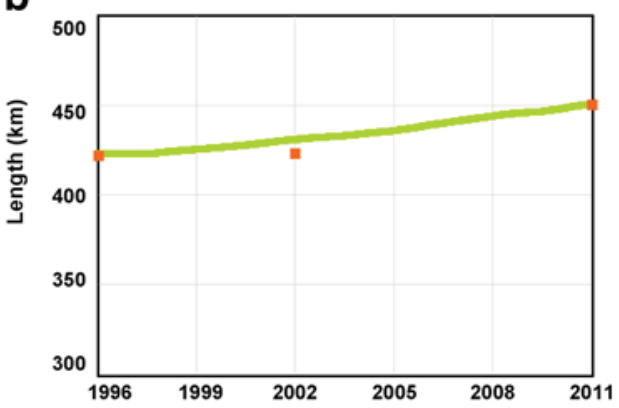

b

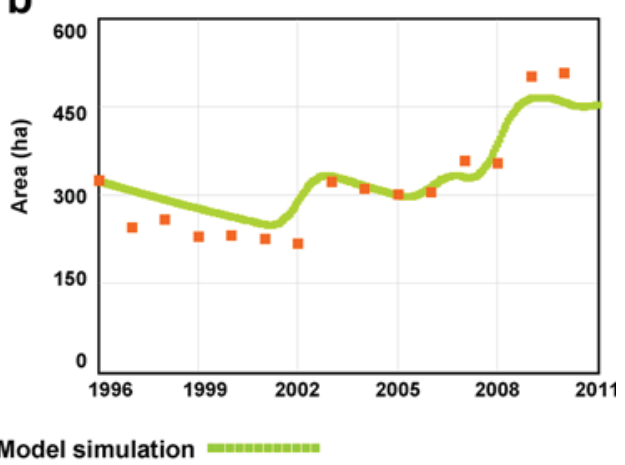

would mean a potential houbara habitat loss around $6.4 \%$ lower than with the BAU scenario.

The management option of more extensive gavias restoration (s.3) would reduce the potential habitat to around 20, 400 ha in 2025, which means an additional loss of $5.7 \%$ compared to BAU.

If the gavias restoration took place under economic growth conditions (s.4), around 6500 ha of potential habitat would be lost at the end of the scenario simulation period, meaning almost 28 and $21 \%$ of additional loss relative to BAU (s.0) and the gavias restoration scenario (s.3), respectively. However, if this management measure was implemented under an economic recession scenario, the potential loss would

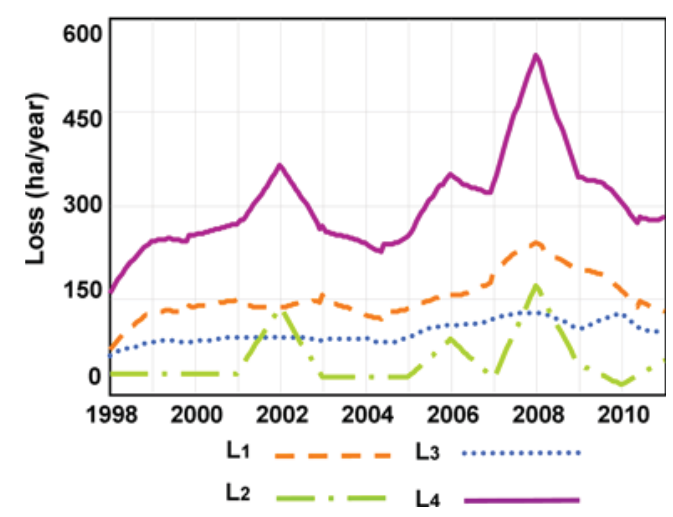

Fig. 5 Contribution of each factor to the loss of houbara potential habitat (loss due to urban expansion $\left(L_{1}\right)$, loss due to new crops $\left(L_{2}\right)$, loss due to roads and tracks $\left(L_{3}\right)$, total contribution to the habitat loss $\left(L_{4}\right)$ be around $6.3 \%$ lower than for s. 3 and almost $1 \%$ lower than with BAU (s.0).

Despite the well-known effect of tourism and urban development on the avifauna (Palomino and Carrascal 2007; Zuberogoitia et al. 2014), our model results show certain influence of the studied economic scenarios on the potential habitat trends. This might be due to the territorial model of the island of Fuerteventura, where tourist and new residential accommodation are mostly concentrated along the coast, as mentioned before (Fig. 1).

\section{Results of a detailed sensitivity analysis of the houbara potential habitat model sector}

The sensitivity analysis (SA) was carried out using different sensitivity analysis techniques, ranging from the simplest class of "one factor at a time" (OAT) screening techniques to general sensitivity techniques, such as a Monte Carlo (MC) simulation. A summary of the methodology and results of the detailed sensitivity analysis of the FSM can be consulted in Appendix 1. In this section, we focus on the results of the SA of the houbara habitat sector.

The OAT analyses revealed that the houbara habitat displayed high sensitivity $\left(S_{i, j} \geq 50 \%\right)$ to three parameters, moderate sensitivity $\left(10 \% \leq S_{i, j}<50 \%\right)$ to six parameters, low sensitivity $\left(S_{i, j}<10 \%\right)$ to 17 of the 110 model parameters and insensitivity $\left(S_{i, j}=0\right)$ to the remaining parameters. The three parameters which showed the highest sensitivity belong to the socio-touristic sector and are closely related to changes 
a

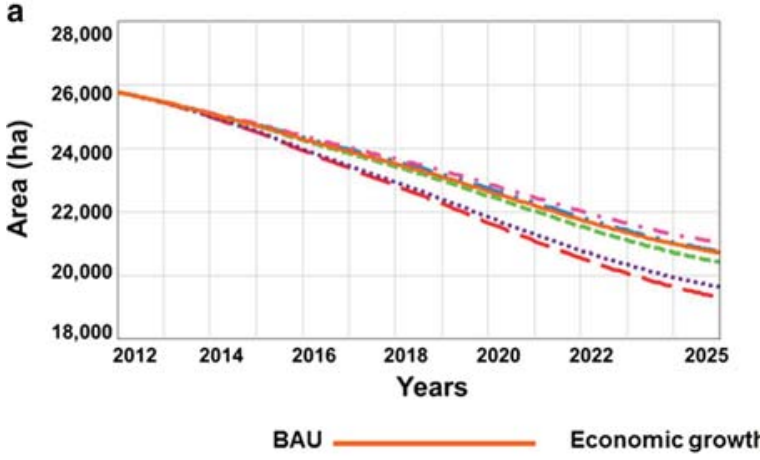

Gavias restoration b

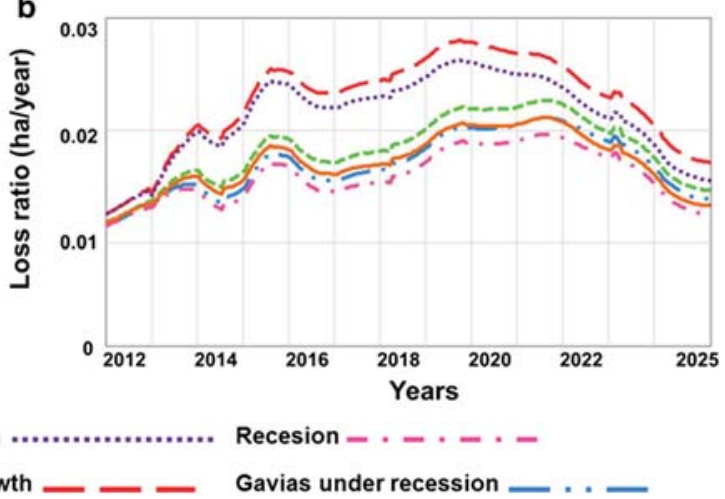

Fig. 6 a Houbara potential habitat under the BAU, economic growth and recession scenarios and under the implementation of the gavias restoration measure under the BAU, economic growth and recession scenarios. b Loss ratio of houbara habitat under such scenarios

in tourist accommodation, tourist arrivals and the increase in the resident population, respectively.

According to the MC results, the houbara habitat would show a low response (variation lower than $30 \%$ with respect to the mean value, with a $95 \%$ confidence interval), using the respective combinations of the most responsive parameters, according to the OAT results.

\section{Discussion}

The results from the dynamic model show a habitat loss of around $13.3 \%$ over the period 1996-2011, which is consistent with the decrease in the Fuerteventura houbara population reported for this period (Martín et al. 1997; Carrascal et al. 2006; Lorenzo 2005; Lorenzo et al. 2007; Carrascal et al. 2008; Schuster et al. 2012). The loss of primary habitat is of particular concern, since it is the habitat with the highest densities of houbaras and it is also scarcer than the secondary habitat. Although the loss of total potential habitat might be considered relatively low, it has probably exerted an important impact on the houbara population, for which censuses showed an overall decrease of around $29 \%$ between 2004/2006 and 2012 (Schuster et al. 2012).

The modelling results also show that land uptake is the factor contributing most to the habitat loss (187 ha per year, on average, in the period 1996-2011). However, indirect effects, such as disturbances caused by roads and tracks, jointly led to a noticeable habitat loss of 87 ha per year on average. Furthermore, off-highway and off-road vehicles might be perceived as predators by wildlife, inducing physiological stress and/or behavioural adjustments (Ouren et al. 2007; Sastre et al. 2009). The effect of the new agricultural areas was less than that of the other factors during the calibration period, with almost 21 ha lost per year on average. The importance of these factors has also been suggested previously (Lorenzo 2004; Carrascal et al. 2008), although such effects have not been quantified previously. These factors should be taken into account in management programmes, since indirect effects could be perceived as less important or even go unnoticed in land planning and conservation processes.

The changes in the potential habitat do not fully explain the changes in the Fuerteventura houbara population. The number of houbaras, censured using standardised methods in the same areas, has shown a $29 \%$ decrease from 2004 to 2011, while the percentage decrease in the potential habitat of the species in nearly the same period (2002 to 2011) was $11 \%$. This may be explained by considering additional processes not addressed in this work - particularly habitat fragmentation, as suggested by Saunders et al. (1991), Andrén (1994) and Fahrig (2003). Furthermore, there is evidence of the existence of additional factors threatening the houbara populations, which were not considered in this work, such as collisions with power lines (Lorenzo 2004; Lorenzo and Genové 2007; Schuster et al. 2012). Besides, overgrazing is widely recognised as a conservation problem for a variety of birds (Pavel 2004). Le Cuziat et al. (2005) found that the houbara clearly avoids areas with a higher stock of goats and sheep. It has been pointed out that a high livestock density has a negative effect on the houbara due to disturbances and the reduction in breeding success (Lavee 1985; Schuster et al. 2012) and to the potential mortality of chicks caused by trampling.

The scenario analysis for the 2012-2025 period shows that the trend of habitat loss would carry on in the future under a "business as usual" scenario and might increase under an economic growth scenario, in which new tourism and residential infrastructures are demanded. A potential lessening of this demand, as expected under an economic recession scenario, might reduce the habitat loss by around $6.4 \%$ compared to BAU.

The reduction in abandoned gavias under a gavias restoration policy has shown a slight negative effect on the secondary habitat of the houbara. It is important to identify this trade-off in case more extensive restoration measures were implemented or if these measures were combined with certain socioeconomic dynamics, since this would have a greater effect 
on the houbara habitat. In this sense, if gavias restoration was implemented under economic growth conditions, the habitat loss might exceed $25 \%$ between 2012 and 2025. The identification and quantification of less obvious trade-offs within environmental objectives and policies should be incorporated as inputs in the decision-making processes (McShane et al. 2011; Thompson et al. 2014). The FSM has been revealed as a useful tool to improve the integral diagnosis of the dynamics of the island and to assess potential conflicts between management options. If the plans for gavias restoration were implemented, in order to recover certain ecosystem services associated with active gavias (Díaz et al. 2011; BanosGonzález et al. 2015), they should take place in abandoned agro-systems outside the potential habitat of the Canarian houbara. Furthermore, compensatory measures should be implemented to guarantee the conservation of this species, such as more effective measures to prevent the loss of its primary habitat - by searching for alternative planning options (Young et al. 2005; Gangoso et al. 2006; Illera et al. 2010; PérezGarcía et al. 2014) or applying stronger controls on the expansion of existing or new urban developments as well as on the construction of new roads and tracks.

Regarding birds, one topic related to Fuerteventura conservation policies and strategic plans is how may potential habitat loss of the houbara affect the steppe avian community on the island? Although the houbara bustard is not a good surrogate of bird biodiversity at different spatial scales (e.g., bird species richness; Carrascal et al. 2012), it can be considered a flagship species_-attracting public attention and raising awareness of more general conservation needs - and may also encapsulate the conservation needs of other species in steppe areas and arid environments (Le Cuziat et al. 2005; Carrascal et al. 2008; Palomino et al. 2008a). Thus, two other flagship species of the steppe and semiarid environments of Fuerteventura share with the houbara similar and very striking habitat preferences for sandy or denudated soils with a low cover of stones or bare volcanic bedrock, located in areas with gently sloping terrain: the cream-coloured courser (Cursorius cursor; Palomino et al. 2008b) and the blackbellied sandgrouse (Pterocles orientalis; Seoane et al. 2010a). Nevertheless, this pattern of habitat preference, for coarse-grained soils, contrasts with those of other autochthonous bird species of broad ecological breadth (e.g., Anthus berthelotii, Bucanetes githagineus, Burhinus oedicnemus, Lanius meridionalis) and with the habitat preferences of the Canary stonechat (Saxicola dacotiae), an endemic species restricted to rocky or stony soil in areas of steep slopes (Seoane et al. 2010b). Therefore, the ecological consequences of the potential habitat loss modelled for the houbara cannot be generalised to all members of the steppe bird community on the island, considering the among-species differences in the orographic and lithological attributes of the landscape responsible for their distribution patterns in Fuerteventura.
Future work, focused on a houbara population model, will take into account other factors driving the houbara demographic dynamics, including habitat fragmentation, population dynamics related to environmental productivity, power lines and the effect of additional disturbance factors such as livestock. Our approach could be applied to other arid systems, once adapted to their specific conditions and target species, in which the indirect effects arising from different trends or management options could threaten the conservation goals.

Acknowledgments The authors thank Mr. Jesus Miñano and Ms. Francisca Carreño for their personal support, which allowed us to carry out this research. Furthermore, we acknowledge the help of Mr. Juan Antonio Lorenzo. This work has been developed as part of the project: "An integrated tool for the sustainable management and the development of an information and participation system in Biosphere Reserves," funded by the Ministry of Industry, Tourism and Commerce, Subprogram: Avanza Competitividad I+D+i 2010-2012. It has been supported also by the IDIGEO Project: "Platform for Research and Development of Geomatic Information Systems," funded by MiCINN Acteparq Year 2009-2011. We especially acknowledge the helpful comments of the editor and anonymous reviewers.

\section{Appendix 1. Model testing}

A set of model testing procedures was applied (Barlas 1996), including dimensional consistency test, extreme conditions tests, sensitivity analysis and goodness of fit test. The model successfully passed these testing procedures for the period 1996-2011.

In relation to extreme conditions tests ( $\mathrm{Li}$ et al. 2012), the model generated the expected results when it was subjected to 25 extreme conditions, such as an unexpected drop in tourist arrivals, an accelerated demand for built-up land, extreme droughts or an increase in grazing (Fig. 7).

The sensitivity analysis was carried out using different sensitivity analysis techniques: "one factor at a time" (OAT) screening techniques (Van Griensven et al. 2002; Sun et al. 2012; Moreau et al. 2013) for the 110 parameters of the model and Monte Carlo (MC) simulations, applied for each of the 18 target model variables of the model, by means of which the robustness of the model's behaviour was assessed (Graham et al. 2002; Refsgaard et al. 2007; Lesnoff et al. 2012).

The OAT analyses for each model parameter allowed the identification and selection of the most sensitive parameters for each of the 18 target model variables used to assess the model's response. The sensitivity index $S_{i, j}$ calculated according to Jørgensen and Fath (2011); Eq. 3 showed the following results: 48 low-sensitivity parameters $\left(\mathrm{S}_{i, j}<10 \%\right), 28$ moderate-sensitivity parameters $\left(10 \% \leq S_{i, j}<50 \%\right)$ and 26 high-sensitivity parameters $\left(S_{i, j} \geq 50 \%\right)$. Of the latter 26 parameters, 18 displayed 
Fig. 7 Simulation of the extreme condition test: "Extreme droughts lead to overgrazing". a Input conditions and $\mathbf{b}$ expected effects
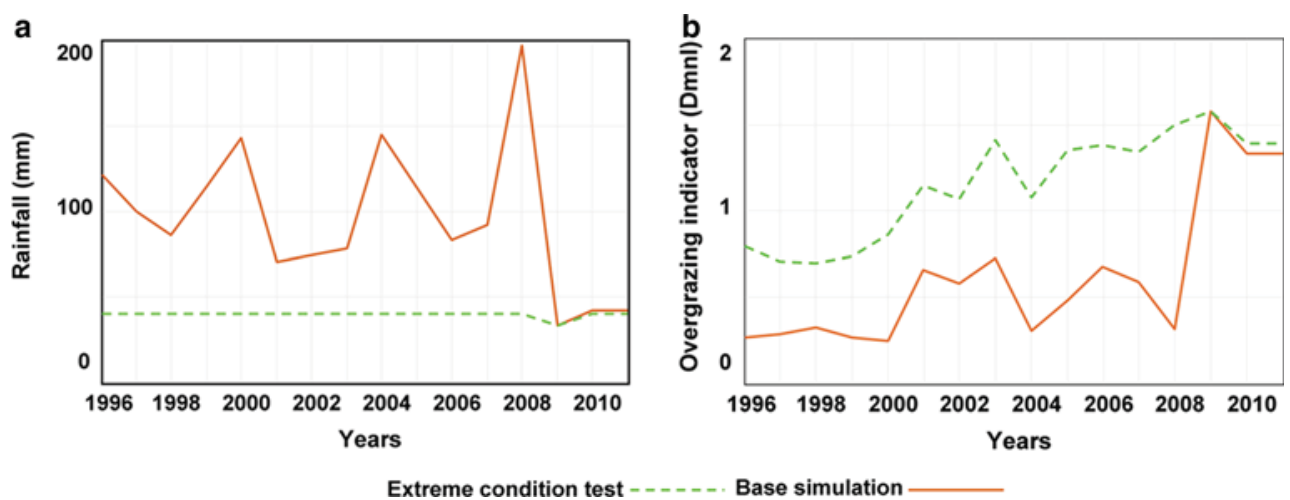

high sensitivity for just one target variable; only three of them showed an $S_{i, j} \geq 100 \%$ for five or more variables.

$S_{i, j}=\left(\frac{O M_{i, t}-^{i, t} O m_{i, t}}{O b_{i, t}}\right) /\left(\frac{P M_{j}-P m_{j}}{P b_{j}}\right) * 100$

where $S_{i, j}$ represents the sensitivity index of the target variable $i$ to the parameter $j ; O M_{i, t}$ and $O m_{i, t}$ are the maximum and minimum values of the $i$ th target variable at time $t ; O b_{i, t}$ represents the base (default) model value of the $i$ th target variable at time $t ; P M_{j}$ and $P m_{j}$ represent the maximum and minimum values of the $j$ th parameter, respectively; and $P b_{\mathrm{j}}$ is the base model value of the $j$ th parameter.

The MC results showed a moderate response of the model outputs to changes in parameter values. Nine of the 18 variables analysed showed a low response (variation coefficientvariation with respect to the mean value, with a $95 \%$ confidence interval-below $50 \%$ ); seven target variables showed a moderate response (variation coefficient between 50 and $100 \%$ ), and two, $\mathrm{CO}_{2} \mathrm{pc}$ and recycled waste, showed a high response (variation above $100 \%$ ).

The comparison of the simulation results with the observed data constitutes a measure of the goodness of fit and, therefore, of the ability of the model to track the actual behaviour of the system and to capture its key questions (Martínez-Moyano and Richardson 2013).

In this work, the mean absolute percentage error (MAPE, Eq. 4), calculated according to Goh and Law (2002) and Oliva (2003), and the normalised root mean square error (NRMSE, Eq. 5), according to Andarizan et al. (2011) and Sepaskhah et al. (2013), were determined.

$$
\begin{aligned}
& M A P E=\frac{1}{n} \sum_{t=1}^{n}\left|\frac{S_{t}-A_{t}}{A_{t}}\right| \\
& N R M S E=\frac{1}{\bar{A}} \sqrt{\frac{1}{n} \sum_{t=1}^{n}\left(S_{t}-A_{t}\right)^{2}}
\end{aligned}
$$

where $\bar{A}$ is the observed average value, $n$ the number of observations and $S_{t}$ and $A_{t}$ the simulated and observed values at time $t$, respectively.

The results for the 20 variables with available observed series show similar values for both statistics. Table 3 shows the values of MAPE and NRMSE for the 20 variables.

A total of 14 variables had a mean absolute percentage error below $10 \%$, which is considered an excellent degree of fit (Goh and Law 2002), whereas four variables achieved a good degree of fit (MAPE of 10-20\%). Only two variables, immigration and emigration, had a degree of fit that was only acceptable according to these authors (MAPE of 20-30\%), which might be related to the lack of reliability of this observed data series.

Regarding the NRMSE calculation, 12 variables presented an excellent degree of fit according to Andarizan et al. (2011) and Sepaskhah et al. (2013), who considered the same intervals, while five variables achieved a good degree of fit and three achieved an acceptable degree of fit: immigration, emigration and golf courses.

It can be concluded that the results of the model testing procedures point to a high degree of fit between the simulated results and the observed series, which supports the ability of the model to track the dynamic of the island of Fuerteventura.

References Appendix 1

Andarizan B, Bannayanb M, Stedutoc P, Mazraeha H, Baratid ME, Baratie MA, Rahnama A. (2011). Validation and testing of the AquaCrop model under full and deficit irrigated wheat production in Iran. Agricultural Water Management, 100: 1-8. doi: 10.1016/j.agwat.2011.08.023

Barlas Y. (1996). Formal aspects of model validity and validation in system dynamics. System dynamics review, 12(3): 183-210.

Goh C, Law R. (2002). Modeling and forecasting tourism demand for arrivals with stochastic nonstationary seasonality and intervention. Tourism Management, 23(5): 499-510. doi: 10.1016/S0261-5177(02)00009-2

Graham AK, Moore J, Choi CY. (2002). How robust are conclusions from a complex calibrated model, really?. A 
Table 3 Detailed results of the goodness of fit test for the 20 variables, using the available series of observed data

\begin{tabular}{llll}
\hline Variables & $n$ & MAPE (\%) & NRMSE (\%) \\
\hline Resident population & 16 & 4.300 & 5.458 \\
Births & 12 & 6.220 & 8.624 \\
Immigration & 16 & 26.184 & 23.384 \\
Emigration & 16 & 32.699 & 31.650 \\
Tourist equivalent population & 16 & 9.517 & 12.035 \\
Tourist accommodation capacity & 16 & 7.287 & 9.400 \\
Occupancy rate & 16 & 8.705 & 10.847 \\
Tourist employment & 13 & 5.386 & 6.634 \\
Houbara habitat & 3 & 0.979 & 1.531 \\
Egyptian vulture population & 13 & 4.539 & 5.080 \\
Urban built-up area & 16 & 2.335 & 2.840 \\
Tracks & 3 & 1.059 & 1.730 \\
Roads & 3 & 0.714 & 1.051 \\
Active crops area & 15 & 10.137 & 11.398 \\
Irrigated crops area & 15 & 11.755 & 13.698 \\
Active gavias area & 15 & 10.492 & 11.550 \\
Natural vegetation area & 3 & 0.280 & 0.446 \\
Golf courses area & 15 & 10.01 & 24.45 \\
Vehicles fleet & 12 & 4.574 & 4.145 \\
Electric energy consumption & 14 & 4.977 & 7.142 \\
\hline & & &
\end{tabular}

$n$ number of observed data

project management model benchmark using fit-constrained Monte Carlo analysis. Proceedings of the XX System Dynamics Conference. System Dynamics Society. Palermo. 28 July-1 August 2002.

Jørgensen SE, Fath B. (2011). Fundamentals of Ecological Modelling (4th Ed.) Elsevier, Amsterdam. (400 pp).

Lesnoff M, Corniaux C, Hiernaux P. (2012). Sensitivity analysis of the recovery dynamics of a cattle population following drought in the Sahel region. Ecological Modelling, 232, 28-39. doi: 10.1016/j.ecolmodel.2012.02.018

Li FJ, Dong SC, Li F. (2012). A system dynamics model for analyzing the ecoagriculture system with policy recommendations. Ecological Modelling, 227: 34-45. doi: 10. 1016/j.ecolmodel.2011.12.005

Martínez-Moyano IJ, Richardson GP. (2013). Best practices in system dynamics modeling. System Dynamics Review, 29(2): 102-23. doi: 10.1002/sdr.1495

Moreau P, Viaud V, Parnaudeau V, Salmon-Monviola J, Durand P. (2013). An approach for global sensitivity analysis of a complex environmental model to spatial inputs and parameters: a case study of an agro-hydrological model. Environmental Modelling \& Software, 47, 74-87. doi: 10. 1016/j.envsoft.2013.04.006

Oliva R. (2003). Model calibration as a testing strategy for system dynamics models. European Journal of Operational
Research, 151(3): 552-68. doi: 10.1016/S0377-2217(02) 00622-7

Refsgaard JC, van der Sluijs JP, Højberg AL, Vanrolleghem PA. (2007). Uncertainty in the environmental modelling process-a framework and guidance. Environmental modelling \& software, 22(11), 1543-1556. doi: 10.1016/j.envsoft.2007.02.004

Sepaskhah AR, Amini-Nejad M, Kamgar-Haghighi AA. (2013). Developing a dynamic yield and growth model for saffron under different irrigation regimes. International Journal of Plant Production, 7(3): 473-504.

Sun XY, Newham LTH, Croke BFW, Norton JP. (2012). Three complementary methods for sensitivity analysis of a water quality model. Environmental Modelling \& Software, 37, 19-29. doi: 10.1016/j.envsoft.2012.04.010

Van Griensven A, Meixner T, Grunwald S, Bishop T, Diluzio M, Srinivasan R. (2006). A global sensitivity analysis tool for the parameters of multi-variable catchment models. Journal of hydrology, 324(1), 10-23. doi: 10.1016/j.jhydrol.2005.09.008

\section{References}

Andrén H (1994) Effects of habitat fragmentation on birds and mammals in landscapes with different proportions of suitable habitat: a review. Oikos 71:355-366

Arechavaleta M, Rodríguez S, Zurita N, García A (2010) Lista de especies silvestres de Canarias. Hongos, plantas y animales terrestres. Gobierno de Canarias. 579 pp

Banos-González I, Martínez-Fernández J, Esteve MA (2013) Simulación dinámica de sistemas socio-ecológicos: sostenibilidad en Reservas de la Biosfera. Ecosistemas 22(3):74-83. doi:10.7818/ECOS.2013. 22-3.11

Banos-González I, Martínez-Fernández J, Esteve MA (2015) Dynamic integration of sustainability indicators in insular socio-ecological systems. Ecol Model 306:130-144. doi:10.1016/j.ecolmodel.2014. 08.014

Barlas Y (1996) Formal aspects of model validity and validation in system dynamics. Syst Dyn Rev 12(3):183-210

Bourass K, Hingrat Y (2015) Diet of released captive-bred North-African houbara bustards. Eur J Wildl Res 61(4):563-574. doi:10.1007/ s10344-015-0930-8

Carrascal LM, Seoane J, Palomino D, Alonso CL (2006) Preferencias de hábitat, estima y tendencias poblacionales de la avutarda hubara Chlamydotis undulata en Lanzarote y la Graciosa (Islas Canarias). Ardeola 53:251-269

Carrascal LM, Palomino D, Seoane J, Alonso CL (2008) Habitat use and population density of the houbara bustard Chlamydotis undulata in Fuerteventura (Canary Islands). Afr J Ecol 46:291-302. doi:10. 1111/j.1365-2028.2008.00971.x

Carrascal LM, Cayuela L, Palomino D, Seoane J (2012) What speciesspecific traits make a bird a better surrogate of native species richness? A test with insular avifauna. Biol Conserv 152:204-211. doi: 10.1016/j.biocon.2012.04.009

del Arco Aguilar MJ, González-González R, Garzón-Machado V, Pizarro-Hernández B (2010) Actual and potential natural vegetation on the Canary Islands and its conservation status. Biodivers Conserv 19(11):3089-3140. doi:10.1007/s10531-010-9881-2 
Díaz FJ, Tejedor M, Jiménez C, Dahlgren RA (2011) Soil fertility dynamics in runoff-capture agriculture, Canary Islands, Spain. Agric Ecosyst Environ 144(1):253-261

Fahrig L (2003) Effects of habitat fragmentation on biodiversity. Annu Rev Ecol Evol Syst 34:487515

Fernández-Palacios JM, Whittaker RJ (2008) The Canaries: an important biogeographical meeting place. J Biogeogr 35(3):379-387

Forrester JW (1961) Industrial dynamics. Pegasus Communications, Waltham, MA, $464 \mathrm{pp}$

Gangoso L, Donázar JA, Scholz S, Palacios CJ, Hiraldo F (2006) Contradiction in conservation of island ecosystems: plants, introduced herbivores and avian scavengers in the Canary Islands. Biodivers Conserv 15:2231-2248. doi:10.1007/s10531-004-7181-4

González JA, Montes C, Rodríguez R, Tapia W (2008) Rethinking the Galapagos Islands as a complex social-ecological system: implications for conservation and management. Ecol Soc 13(2):13

GRAFCAN [homepage on the internet] (2011). Mapa de Vegetación, Fuerteventura (2002/2003). Available from: http://www.idecan. grafcan.es. Accessed Sep 2011

Hingrat Y, Ysnel F, Saint Jalme M, Le Cuziat J, Béranger PM, Lacroix F (2007) Assessing habitat and resource availability for an endangered desert bird species in eastern Morocco: the Houbara Bustard. Biodivers Conserv 16(3):597-620. doi:10. 1007/s10531-005-0603-0

Illera JC, Von Wehrden H, Wehner J (2010) Nest site selection and the effects of land use in a multi-scale approach on the distribution of a passerine in an island arid environment. J Arid Environ 74(11): 1408-1412. doi:10.1016/j.jaridenv.2010.04.012

IUCN (2009) The World Conservation Union. Red List of Threatened Species. Available from: http://www.iucnredlist.org

Jørgensen SE, Nielsen SN (2015) A carbon cycling model developed for the renewable Energy Danish Island, Samsø. Ecological Modelling, 306:106-120. doi:10.1016/j.ecolmodel.2014.06.004

Jørgensen JE, Bendoricchio G (2001) Fundamentals of ecological modelling. Elsevier, Amsterdam, $530 \mathrm{pp}$

Kelly RA, Jakeman AJ, Barreteau O, Borsuk ME, ElSawah S, Hamilton SH, ... Voinov AA (2013) Selecting among five common modelling approaches for integrated environmental assessment and management. Environ Model Softw 47:159-81. doi: 10.1016/j.envsoft. 2013.05.005

Lavee D (1985) The influence of grazing and intensive cultivation on the population size of the Houbara Bustard in the Northern Negev in Israel. Bustard Stud 3:103-107

Le Cuziat J, Lacroix F, Roche P, Vidal E, Medail F, Orhant N, Beranger PM (2005) Landscape and human influences on the distribution of the endangered North African houbara bustard (Chlamydotis undulata undulata) in Eastern Morocco. Anim Conserv 8(2):143152

Lorenzo JA (2004) Avutarda Hubara Canaria, Chlamydotis undulata fuertaventurae. In: Madroño A, González C, Atienza JC (eds) Libro rojo de las aves de España. Ministerio de Medio AmbienteSEO/BirdLife, Madrid

Lorenzo JA (2005) Último censo de avutarda hubara canaria. El Escribano Digital, 51: 11-12. http://www.seo.org/media/docs/ 0413t El\%20Escribano\%20Digital\%2051.pdf. Acceded 24 Jun 2011

Lorenzo JA, Genové J (2007) Mortalidad de aves en los tendidos eléctricos de los ambientes esteparios de Lanzarote y Fuerteventura, con especial referencia a la avutarda hubara. SEO/ BirdLife. La Laguna, Tenerife. $121 \mathrm{pp}$

Lorenzo JA, González C, Hernández MA, Delgado JD (2007) La avutarda hubara en España. Población en 2004-2006 y método de censo. SEO/BirdLife, Madrid

Martín A, Lorenzo JA. (2001). Aves del archipiélago canario. Francisco Lemus Editor. La Laguna.
Martín-Esquivel JL, Fernández-Palacios JM (2001) Conservación y desarrollo: el difícil equilibrio. In: Fernández-Palacios JM, Esquivel JL (eds). Naturaleza de las Islas Canarias. Ecología y Conservación, Turquesa Ediciones, Tenerife, pp 423-429

Martín A, Nogales M, Hernández MA, Lorenzo JA, Medina FM, Rando JC (1996) Status, conservation and habitat selection of the Houbara Bustard Chlamydotis undulata fuertaventurae on Lanzarote (Canary Islands). Bird Conserv Int 6:229-239

Martín A, Lorenzo JA, Hernández MA, Nogales M, Medina FM, Delgado JD, Naranjo JJ, Quilis V, Delgado G (1997) Distribution, status and conservation of the Houbara Bustard Chlamydotis undulata fuertaventurae Rothschild y Hartert, 1894, in the Canary Islands, November-December 1994. Ardeola 44:61-69

Martínez-Fernández J, Esteve-Selma MA, Baños-González I, Carreño F, Moreno A (2013) Sustainability of Mediterranean irrigated agrolandscapes. Ecol Model 248:11-19. doi:10.1016/j.ecolmodel.2012. 09.018

Martínez-Moyano IJ, Richardson GP (2013) Best practices in system dynamics modeling. Syst Dyn Rev 29(2):102-123. doi:10.1002/ sdr. 1495

McShane TO, Hirsch PD, Trung TC, Songorwa AN, Kinzig A, Monteferri B et al (2011) Hard choices: making trade-offs between biodiversity conservation and human well-being. Biol Conserv 144(3):966-972

Oliva R (2003) Model calibration as a testing strategy for system dynamics models. Eur J Oper Res 151(3):552-568. doi:10.1016/S03772217(02)00622-7

Otto R, Krüsi BO, Kienast F (2007) Degradation of an arid coastal landscape in relation to land use changes in Southern Tenerife (Canary Islands). J Arid Environ 70(3):527-539. doi:10.1016/j.jaridenv. 2007.02.001

Ouren DS, Haas C, Melcher CP, Stewart SC, Ponds PD, Sexton NR, Burris L, Fancher T, Bowen ZH (2007) Environmental effects of off-highway vehicles on Bureau of Land Management lands: A literature synthesis, annotated bibliographies, extensive bibliographies, and internet resources: U.S. Geological Survey, Open-File Report 2007-1353, $225 \mathrm{pp}$

Palacios CJ, Tella JL (2003) Aves esteparias de Canarias: una comunidad en peligro. Quercus 209:14-21

Palomino D, Carrascal LM (2007) Habitat associations of a raptor community in a mosaic landscape of Central Spain under urban development. Landsc Urban Plan 83(4):268-274. doi:10.1016/j. landurbplan.2007.04.011

Palomino D, Seoane J, Alonso CL (2008a) Conservar la hubara canaria, cuestión de prioridades. Abundancia, distribución y preferencia de hábitat de la hubara en Canarias. Quercus 273: $22-27$

Palomino D, Seoane J, Carrascal LM, Alonso CL (2008b) Competing effects of topographic, lithological, vegetation structure and human impact in the habitat preferences of the cream-coloured courser. J Arid Environ 72(4):401-410

Pavel V (2004) The impact of grazing animals on nesting success of grassland passerines in farm land and natural habitats: a field experiment. Folia Zool 53:171-178

Pérez I, Tenza A, Anadón JD, Martínez-Fernández J, Pedreño A, Giménez A (2012) Exurban sprawl increases the extinction probability of a threatened tortoise due to pet collections. Ecol Model 245: 19-30. doi:10.1016/j.ecolmodel.2012.03.016

Pérez-García JM, Sebastián-González E, Alexander KL, Sánchez-Zapata JA, Botella F (2014) Effect of landscape configuration and habitat quality on the community structure of waterbirds using a man-made habitat. Eur J Wildl Res 60(6):875-883. doi:10.1007/s10344-0140854-8

Rasmussen LV, Rasmussen K, Reenberg A, Proud S (2012) A system dynamics approach to land use changes in agro-pastoral systems on the desert margins of Sahel. Agric Syst 107:56-64 
Rodríguez-Rodríguez A, Mora JL, Arbelo C, Bordon J (2005) Plant succession and soil degradation in desertified areas (Fuerteventura, Canary Islands, Spain). Catena 59(2):117-131

Santana-Jiménez Y, Hernández JM (2011) Estimating the effect of overcrowding on tourist attraction: the case of Canary Islands. Tour Manag 32(2):415-425. doi:10.1016/j.tourman.2010.03.013

Sastre P, Ponce C, Palacín C, Martín CA, Alonso JC (2009) Disturbances to great bustards (Otis tarda) in central Spain: human activities, bird responses and management implications. Eur J Wildl Res 55:425432. doi:10.1007/s10344-009-0254-7

Saunders DA, Hobbs RJ, Margules CR (1991) Biological consequences of ecosystem fragmentation: a review. Conserv Biol 5:18-32

Schuster C, Iglesias-Lebrija JJ, Carrascal LM (2012) Recent population trends of the houbara bustard in the Canary Islands. Methods and conservation status. Anim Biodivers Conserv 35(1):125-139

Seddon PJ, van Heezik Y (1996) Seasonal changes in Houbara bustard Chlamydotis undulata macqueenii numbers in Harrat Al Harrah, Saudi Arabia: implications for managing a remnant population. Biol Conserv 75(2):139-146

Seoane J, Carrascal LM, Palomino D, Alonso CL (2010a) Population size and habitat relationships of Black-bellied Sandgrouse, Pterocles orientalis, in the Canary Islands, Spain. Bird Conserv Int 20:161175

Seoane J, Kouri A, Illera JC, Palomino D, Alonso CL, Carrascal LM (2010b) New data on the population, distribution and habitat preferences of the Canary Islands stonechat Saxicola dacotiae. Ardeola $57: 387-405$
Seoane J, Carrascal LM, Palomino D (2011) Assessing the ecological basis of conservation priority lists for bird species in an island scenario. J Nat Conserv 19:103-115

Silva JP, Santos M, Queirós L, Leitão D, Moreira F, Pinto M, Cabral JA (2010) Estimating the influence of overhead transmission power lines and landscape context on the density of little bustard Tetrax tetrax breeding populations. Ecol Model 221(16):1954-1963. doi: 10.1016/j.ecolmodel.2010.03.027

Thompson ID, Okabe K, Parrotta JA, Brockerhoff E, Jactel H, Forrester DI, Taki H. (2014). Biodiversity and ecosystem services: lessons from nature to improve management of planted forests for REDDplus. Biodivers Conserv 23:2613-2635. doi:10.1007/s10531-0140736-0

Voinov A, Shugart HH (2013) 'Integronsters', integral and integrated modeling. Environ Model Softw 39:149-158. doi:10.1016/j. envsoft.2012.05.014

Young J, Watt A, Nowicki P, Alard D, Clitherow J, Henle K et al (2005) Towards sustainable land use: identifying and managing the conflicts between human activities and biodiversity conservation in Europe. Biodivers Conserv 14(7):1641-1661. doi:10.1007/ s10531-004-0536-Z

Zhao R, Zhong S (2015) Carbon labelling influences on consumers' behaviour: a system dynamics approach. Ecol Indic 51:98-106. doi:10.1016/j.ecolind.2014.08.030

Zuberogoitia I, Zabala J, Martínez JE, González-Oreja JA, López-López P (2014) Effective conservation measures to mitigate the impact of human disturbances on the endangered Egyptian vulture. Anim Conserv 17(5):410-418. doi:10.1111/acv.12107 